\title{
THE EFFECT OF THE FIRST FERTILE FLOOR ON QUALITATIVE - QUANTITATIVE PROPERTIES OF SOYBEAN SEED
}

\author{
S. Anđelović ${ }^{1}$, S. Maksimovic ${ }^{2}$, D. Savić ${ }^{3}$, Z. Tomic ${ }^{4}$, D. Delić ${ }^{2}$ \\ ${ }^{1}$ Delta Agrar doo Belgrade, Serbia \\ ${ }^{2}$ Institute of Soil Science, Belgrade, Serbia \\ ${ }^{3}$ University of Belgrade, Faculty of Agriculture, Zemun, Serbia \\ ${ }^{4}$ Institute of Animal Husbandry, Belgrade, Serbia \\ Corresponding author: srdjan.andjelovic@deltaagrar.rs \\ Communication
}

\begin{abstract}
The aim of this study was to determine the effect of height of the first fertile floor on the qualitative and quantitative characteristics of soybean seeds. For qualitative traits the focus was on the energy of germination and seed germination of the studied genotypes investigated per soybean plant and the first fertile floor of the plant. Results of research indicated that there were significant differences between genotypes observed by morphological characteristics (plant height, height of first fertile floor, number of fertile floors, number of pods and seeds, seed weight, etc.) as well as qualitative properties (energy of germination and seed germination). Cultivar Gorštak, with genetically incorporated height of the first fertile floor $(12.38 \mathrm{~cm})$, was superior to other two genotypes. A similar trend was found in other morphological analyses. Based on energy of germination and seed germination of all fertile floors per plant, there were no significant differences between soybean genotypes. However, of paramount importance are the established values of these parameters relevant to the first fertile floor. Cultivar Gorštak had significantly higher energy of germination $(90.46 \%)$ and total germination $(91.00 \%)$ compared to the other two genotypes.
\end{abstract}

Key words: soybean, genotype, seed quality, germination, yield

\section{Introduction}

The soybean (Glycine max) is annual legume widely grown for its edible bean which has numerous uses. The plant is classed as an oilseed rather than a pulse. Soybean genomics is of great interest as one of the most economically important crops and a major food source. Most soybeans are processed for their oil and protein for the animal feed industry. Protein content accounts for about $40 \%$ of dry soybeans while carbohydrates and oils account for about $35 \%$ and $20 \%$, 
respectively. Because soybeans have high protein content, they are a major ingredient in livestock feed. A smaller percentage is processed for human consumption and made into products including soy milk, soy flour, soy protein, tofu and many retail food products. Soybeans are also used in many non-food (industrial) products. Recently, soybean oil has caused considerable attention due to its increased use for biodiesel production. High quality soybeans are grown, harvested and purchased by the seed industry to be used as seed for the next year's crop. Researchers in the seed industry focus on developing new soybean varieties with outstanding characteristics including high yield, lodging resistance, nematode resistance, herbicide tolerance, and many other desirable characteristics (Chung et al., 2003; Scott et al., 1970; Aćimović, 1988). Height of first fertile floor is of very practical importance in the production of soybeans, especially in seed production. In conditions of low first fertile floor $(<10 \mathrm{~cm})$ crop losses increased by over $5 \%$ with a significant reduction of seed quality (energy of germination, germination and health). Particularly aggravating circumstance in seed crops with low first fertile floor is poor quality of seeds from lower floors which get into the total amount of processed and dressed seeds causing decrease of seed quality.

\section{Materials and Methods}

Two cultivars (Tijana and Gorstak) and one homozygous soybean line (BG-L-4601) with different levels of height of first fertile floor were examined (Table 1). Cultivars Tijana, BG-L-4601 and Gorstak belonged to 0, I and II maturity group, respectively. The experiment was carried out in 2011 at the experimental field of AD Progress, Stara Pazova, in completely randomized design with four replicates. The cultivars had the same sowing and germination date. The harvest date was 9. 15. and 24. September for Tijana, BG-L-4601 and Gorstak, respectively. Number of plants in harvest ha ${ }^{-1}$ were 480000,430000380000 for Tijana, BG-L-4601 and Gorstak, respectively. Experimental plot was $5 \mathrm{~m} \times 2 \mathrm{~m}$ with $50 \mathrm{~cm}$ distance row-to-row. Each plot was planted as four rows of $5 \mathrm{~m}$ length. During the growing season, plant phenological and phyto-pathological observations were carried out. After the harvest, morphological analysis of plants from two inner rows was done. Also, quality of seed (energy of germination, seed germination and seed health especially, on the first fertile floor) was determined. All data were subject to ANOVA using the statistical analysis system (SPSS, 2007. SYSTAT version 16: Statistics. SPSS Chicago, IL, USA.). Means of all parameters were calculated and the differences tested for significance using the LSD test at the 0.5 probability level. Correlation coefficients were calculated to study the associative relations among the measured traits. 


\section{Results and Discussion}

Sowing was performed at optimal time with a homogeneous germination of plants which provide a high quality of used seed in all three genotypes. Harvesting is done manually after achievement of physiological maturity of certain genotypes. Morphological analysis of plants related to plant height showed a high degree of significance of differences $(\mathrm{P}<0.05)$ between all three genotypes (Table 1). Cultivar Gorštak was superior $(110.83 \mathrm{~cm})$, while the differences between cultivar Tijana $(98.15 \mathrm{~cm})$ and line BG-4601-L $(90.73 \mathrm{~cm})$ were also highly significant.

Table 1. Plant height, height of the first fertile floor and number of first floor of soybean cultivars, line

\begin{tabular}{|c|c|c|c|c|c|c|c|c|c|}
\hline \multirow{3}{*}{ Replication } & \multicolumn{9}{|c|}{ Cultivar, line } \\
\hline & \multicolumn{3}{|c|}{$\begin{array}{l}\text { Plant height } \\
(\mathrm{cm})\end{array}$} & \multicolumn{3}{|c|}{$\begin{array}{l}\text { The height of the first fertile } \\
\text { floor }(\mathrm{cm})\end{array}$} & \multicolumn{3}{|c|}{$\begin{array}{l}\text { The number of first floor } \\
(\mathrm{cm})\end{array}$} \\
\hline & Tijana & BG-L-4601 & Gorštak & Tijana & BG-L-4601 & Gorštak & Tijana & BG-L-4601 & Gorštak \\
\hline $\mathrm{I}$ & 98,10 & 92,15 & 110,10 & 10,25 & 7,00 & 12,75 & 14,05 & 13,75 & 18,90 \\
\hline II & 97,00 & 89,00 & 112,00 & 11,00 & 7,15 & 12,60 & 14,00 & 13,60 & 18,80 \\
\hline III & 99,00 & 90,00 & 110,05 & 10,00 & 6,90 & 12,05 & 13,95 & 14,00 & 19,15 \\
\hline IV & 98,50 & 91,75 & 111,15 & 9,85 & 6,85 & 12,10 & 14,10 & 13,55 & 18,95 \\
\hline \multirow[t]{2}{*}{$\mathrm{X}$} & 98,15 & 90,73 & 110,83 & 10,28 & 6,98 & 12,38 & 14,03 & 13,73 & 18,95 \\
\hline & \multicolumn{3}{|c|}{ LSD $0,05=1,798$} & \multicolumn{3}{|c|}{ LSD $0,05=0,586$} & \multicolumn{3}{|c|}{ LSD $0.05=0,238$} \\
\hline
\end{tabular}

Similar trends have been shown related to the height of first fertile floor (Table 1). Cultivar Gorštak $(12.38 \mathrm{~cm})$ had significantly higher height of the first fertile floor compared to other two genotypes, but also significant differences were found between cultivar Tijana $(10.28 \mathrm{~cm})$ and line BG-L-4601 $(6.98 \mathrm{~cm})$. Height of the first fertile floor is under very important influence of genetic factors which is confirmed by other researchers (Plazinić, 1987; Plazinić et al., 1999). Number of fertile floors per plant was very significantly higher in the cultivar Gorštak (18.95) than the other two genotypes, while the differences between cultivar Tijana (14.03) and the line BG-L-4601 (13.73) were also, significant (Table 1).

The number of pods per plant in the cultivar Gorštak (48.09) was significantly higher than in other two genotypes (40.46 - Tijana, 40.16 - line BG-L4601), while the differences between these two genotypes were also significant (Table 2). The number of pods per plant generally is higher in the dominant genotypes (Sincler and Shurtleft, 1975; Scott and Aldrich, 1970). The number of seeds per plant followed the trend of number of pods per plant. Highly significant differences between cultivar Gorštak (115.41) and the other two genotypes were 
established, while there were no significant differences between the cultivar Tijana (96.89) and the line BG-L-4601 (97.23) (Table 2). Similar results have been reported by Andjelović et al. (2000) and Plazinić (1987) indicating a significant correlation between the number of pods and seeds. The number of pods on the first fertile floor of Tijana and BG-L-4601 (3.98 - Tijana, 4.08 - BG-L-4601) was significantly higher in relation to the cultivar Gorštak (3.01), while the there was no difference between the first two mentioned genotypes (Table 2). The temperature had significant effect on the number pods and seeds per plant (Wigham and Minor, 1978)

Table 2. The number of pods and seeds per plant and the number of pods on the first fertile floor of soybean cultivars, line

\begin{tabular}{|c|c|c|c|c|c|c|c|c|c|}
\hline \multirow{3}{*}{ Replication } & \multicolumn{9}{|c|}{ Cultivar, line } \\
\hline & \multicolumn{3}{|c|}{ The number of pods per plant } & \multicolumn{3}{|c|}{ The number of seeds per plant } & \multicolumn{3}{|c|}{$\begin{array}{l}\text { The number of pods } \\
\text { on the first fertile floor }\end{array}$} \\
\hline & Tijana & BG-L-4601 & Gorštak & Tijana & BG-L-4601 & Gorštak & Tijana & BG-L-4601 & Gorštak \\
\hline I & 41,00 & 40,00 & 48,15 & 99,22 & 98,00 & 115,56 & 4,15 & 4,10 & 3,10 \\
\hline II & 40,10 & 39,75 & 47,95 & 96,44 & 96,75 & 115,65 & 3,90 & 4,05 & 3,00 \\
\hline III & 40,75 & 39,80 & 48,00 & 96,00 & 95,52 & 114,83 & 3,85 & 4,00 & 2,95 \\
\hline IV & 40,00 & 41,10 & 48,25 & 95,90 & 98,64 & 115,60 & 4,00 & 4,15 & 3,00 \\
\hline \multirow[t]{2}{*}{$\mathrm{X}$} & 40,46 & 40,16 & 48,09 & 96,89 & 97,23 & 115,41 & 3,98 & 4,08 & 3,01 \\
\hline & & & & \multicolumn{3}{|c|}{ LSD $0,05=1,966$} & \multicolumn{3}{|c|}{ LSD $0,05=0,148$} \\
\hline
\end{tabular}

Number of seeds on the first floor of the first two genotypes (9.38 - Tijana, 9.55 - BG-L-4601) (Table 3) was very significantly higher compared to cultivar Gorštak (5.34), whereas differences between the first two genotypes were not statistically significant. The mass of seeds per plant was very significantly different between the genotypes (Table 3). Cultivar Gorštak (19.15 g) was highly significantly superior in regard to these quantitative traits in relation to the other two genotypes. At the same time, Tijana $(15.53 \mathrm{~g})$ had significantly greater mass of seeds in relation to the line BG-L-4601 (13.83 g). Differences in seed weight per plant were formed as a result of a domination of genetic factors and the interaction between genotype and agricultural conditions. Similar results have been reported by Andelović et al. (2000). Seed weight on the first fertile floor differed significantly between the three genotypes (Table 3$)$. Cultivar Gorštak $(0.80 \mathrm{~g})$ had significantly lower seed weight than the other two genotypes, whereas no significant differences were established between them (1.69 g - Tijana, $1.60 \mathrm{~g}$ BG-L-4601).

Energy of germination and seed germination are very important qualitative properties and their practical values directly or indirectly influence the production of seeds and grains in field conditions. 
Table 3. The number of seeds and seed weight on the first fertile floor of soybean, seed weight per plant of a soybean cultivars, line

\begin{tabular}{|c|c|c|c|c|c|c|c|c|c|}
\hline \multirow{3}{*}{ Replication } & \multicolumn{9}{|c|}{ Cultivar, line } \\
\cline { 2 - 11 } & \multicolumn{3}{|c|}{$\begin{array}{c}\text { The number of seeds on the } \\
\text { first fertile floor }\end{array}$} & \multicolumn{3}{c|}{$\begin{array}{c}\text { Seed weight per plant } \\
(\mathrm{g})\end{array}$} & \multicolumn{3}{c|}{$\begin{array}{c}\text { Seed weight on the first fertile } \\
\text { floor }(\mathrm{g})\end{array}$} \\
\cline { 2 - 11 } & Tijana & BG-L-4601 & Gorštak & Tijana & BG-L-4601 & Gorštak & Tijana & BG-L-4601 & Gorštak \\
\hline I & 9,96 & 9,63 & 5,52 & 16,01 & 14,01 & 19,10 & 1,80 & 1,60 & 0,83 \\
\hline II & 9,00 & 9,56 & 5,46 & 15,40 & 13,68 & 19,95 & 1,62 & 1,57 & 0,82 \\
\hline III & 8,95 & 9,35 & 5,00 & 15,62 & 13,50 & 18,80 & 1,62 & 1,62 & 0,75 \\
\hline IV & 9,60 & 9,65 & 5,36 & 15,10 & 14,11 & 18,76 & 1,73 & 1,61 & 0,81 \\
\hline X & 9,38 & 9,55 & 5,34 & 15,53 & 13,83 & 19,15 & 1,69 & 1,60 & 0,80 \\
\hline & \multicolumn{7}{|l|}{ LSD $0,05=0,515$} & \multicolumn{7}{|c|}{ LSD $0,05=0,701$} & & LSD $0,05=0,090$ & \\
\hline
\end{tabular}

Energy of seed germination of all fertile floors showed no significant differences between genotypes (Table 4). Both cultivars - Tijana 90.58\% and 91.15\% as Cultivar Gorštak and the line BG-L-4601 (90.56\%) had high values for this parameter as qualitative property of seed. Seed germination of all fertile floors followed the energy of germination without significant differences between genotypes (91.88\% Tijana, 91.50\% BG-L-4601, 91.80\% Cultivar Gorštak) (Table $4)$.

Table 4. Seed germination energy and seed germination of all fertile floors of soybean

\begin{tabular}{|c|c|c|c|c|c|c|}
\hline \multirow{2}{*}{ Replication } & \multicolumn{5}{|c|}{ Cultivar, line } \\
\cline { 2 - 7 } & \multicolumn{5}{|c|}{$\begin{array}{c}\text { Seed germination energy of all fertile } \\
\text { floor (\%) }\end{array}$} & \multicolumn{2}{c|}{$\begin{array}{c}\text { Seed germination of all fertile floors } \\
(\%)\end{array}$} \\
\cline { 2 - 7 } & Tijana & BG-L-4601 & Gorštak & Tijana & BG-L-4601 & Gorštak \\
\hline I & 89,70 & 90,35 & 92,00 & 92,00 & 91,50 & 92,00 \\
\hline II & 91,00 & 91,20 & 91,70 & 92,50 & 92,00 & 92,50 \\
\hline III & 90,10 & 89,95 & 90,90 & 91,00 & 91,00 & 91,70 \\
\hline IV & 91,50 & 90,75 & 90,00 & 92,00 & 91,50 & 91,00 \\
\hline X & 90,58 & 90,56 & 91,15 & 91,88 & 91,50 & 91,80 \\
\hline & LSD 0,05=1,227 & \multicolumn{5}{|c|}{ LSD 0,05=0,903 } \\
\hline
\end{tabular}

Energy of seed germination on the first fertile floor was significantly different between all genotypes (Table 5). Very significantly higher values of the qualitative properties of seeds were determined in the cultivar Gorštak $(90.46 \%)$ compared to the other two genotypes. At the same time there was highly significant difference between cultivar Tijana (82.80\%) and line BG-L-4601 (66.84\%). 
Differences between the genotypes showed very significant participation of genetic factors, which has been reported in other studies (Plazinić, 1987; Brim, 1973.). Seed germination on the first fertile floor differed significantly between genotypes (Table 5). Very significant differences were observed between cultivars Gorštak $(91.00 \%)$ and other two genotypes. At the same time, also, a significant difference between the qualitative characteristics of the cultivar Tijana (84.45\%) and line BGL-4601 (66.98\%) was established.

Table 5. Energy of seed germination and seed germination of the first fertile floor of soybean

\begin{tabular}{|c|c|c|c|c|c|c|}
\hline \multirow{2}{*}{ Replication } & \multicolumn{6}{|c|}{ Cultivar, line } \\
\cline { 2 - 7 } & \multicolumn{2}{|c|}{$\begin{array}{c}\text { Energy of seed germination of the } \\
\text { first fertile floor (\%) }\end{array}$} & \multicolumn{2}{c|}{$\begin{array}{c}\text { Seed germination of the first fertile } \\
\text { floor (\%) }\end{array}$} \\
\cline { 2 - 7 } & Tijana & BG-L-4601 & Gorštak & Tijana & BG-L-4601 & Gorštak \\
\hline I & 82,80 & 68,00 & 90,00 & 84,00 & 68,00 & 91,50 \\
\hline II & 83,00 & 66,35 & 90,75 & 85,10 & 66,55 & 91,00 \\
\hline III & 83,50 & 66,56 & 91,00 & 85,00 & 66,00 & 91,00 \\
\hline IV & 81,90 & 67,00 & 90,10 & 83,70 & 67,35 & 90,50 \\
\hline X & 82,80 & 66,84 & 90,46 & 84,45 & 66,98 & 91,00 \\
\hline
\end{tabular}

Correlations between investigated parameters are presented in Table 6 . Plant height showed a high degree of significance of correlation with all examined traits except germination and seed germination of all fertile floors. Height of first fertile floor was positively correlated with the number of fertile floors $(\mathrm{r}=0,813)$ number of pods $(r=0,799)$ and seeds $(r=0,774)$ per plant and the energy $(r=$ $0,986)$ and germination $(r=0,983)$ of seeds on the first fertile floor. At the same time, it was negatively correlated with number of pods $(r=-0,823)$ and seeds $(r=-$ 0,801 ) on the first fertile floor. The number of fertile floors was positively correlated with number of pods $(r=0,990)$ and seeds $(r=0,989)$ per plant, seed weight per plant $(r=0,944)$, and negatively correlated with number of pods $(r=-$ $0,986)$ and seeds $(r=-0,990)$ as well as the mass of native seeds on the first fertile floor $(r=-0,980)$. The number of pods on the first fertile floor was negatively correlated with plant height $(r=-0,936)$, height of first fertile floor $(r=-0,823)$, number of fertile floor per plant $(r=-0,986)$ and the number of pods $(r=-0,987)$ and seeds per plant $(\mathrm{r}=-0,957)$.

Number of seeds on the first fertile floor was negatively correlated with plant height $(r=-0,924)$, height of first fertile floor $(r=-0,801)$, the number of fertile floors $(r=-0,990)$ and number of pods $(r=-0,979)$ and seeds per plant $(r=-$ $0,969)$ and positively correlated with number of pods on the first fertile floor $(\mathrm{r}$ $=0,997)$. Seed weight per plant was positively correlated with plant height $(\mathrm{r}=$ 
$0,988)$, height of first fertile floor $(\mathrm{r}=0,930)$, the number of fertile floors $(\mathrm{r}=$ $0,944)$, number of pods $(\mathrm{r}=0,948)$ and seeds per plant $(\mathrm{r}=0,937)$ and negatively correlated with number of pods $(r=-0,933)$ and seeds $(r=-0,926)$ on the first fertile floor.

Table 6. Correlations between investigated parameters of some soybean cultivars, line

\begin{tabular}{|c|c|c|c|c|c|c|c|c|c|c|c|c|c|}
\hline $\begin{array}{l}{ }^{\mathrm{a}} \text { Parame } \\
\text { ters }\end{array}$ & \begin{tabular}{|l|}
$\mathrm{V}$ \\
$\mathrm{cm}$
\end{tabular} & $\begin{array}{l}\mathrm{VE} \\
\mathrm{cm}\end{array}$ & BETŽ & BM & BS & BMŽ1 & BSŽ1 & $\begin{array}{l}\text { QS } \\
\mathrm{g}\end{array}$ & \begin{tabular}{|l} 
QSŽ1 \\
$\mathrm{g}$
\end{tabular} & $\begin{array}{l}\text { EK } \\
\% \\
\end{array}$ & $\begin{array}{l}\text { UKS } \\
\% \\
\end{array}$ & $\begin{array}{l}\text { EKŽ1 } \\
\% \\
\end{array}$ & $\begin{array}{l}\text { UKSŽ1 } \\
\%\end{array}$ \\
\hline V & 1 & $0.939 * * *$ & $\begin{array}{l}0.939 * * \\
*\end{array}$ & $0.936^{* * *}$ & $0.917 * * *$ & $\begin{array}{c}- \\
.0 .936 * * *\end{array}$ & $-0.924 * * *$ & $0.988^{* * *}$ & $-0.877 * * *$ & $0.335^{\mathrm{ns}}$ & $0.175^{\mathrm{ns}}$ & $0.935^{* * *}$ & $0.913 * * *$ \\
\hline VE & & 1 & $0.813^{* *}$ & $0.799 * *$ & $0.774 * *$ & $-0.823 * * *$ & $-0.801 * *$ & $0.930 * * *$ & $-0.725 * *$ & $0.358^{\text {ns }}$ & $0.349^{\text {ns }}$ & $0.986 * * *$ & $0.983 * * *$ \\
\hline BETŽ & & & 1 & $0.990 * * *$ & $0.989 * * *$ & $-0.986 * * *$ & $-0.990 * * *$ & $0.944 * * *$ & $-0.980 * * *$ & $0.36^{2 \mathrm{~ns}}$ & $0.099^{\mathrm{ns}}$ & $0.779 * *$ & $0.742 * *$ \\
\hline BM & & & & 1 & $0.995 * * *$ & $-0.970 * * *$ & $-0.979 * * *$ & $0.948 * * *$ & $-0.975 * * *$ & $0.341^{\mathrm{ns}}$ & $0.082^{\text {ns }}$ & $0.767 * *$ & $0.730 * *$ \\
\hline BS & & & & & 1 & $-0.957 * * *$ & $-0.969 * * *$ & $0.937 * * *$ & $-0.973 * * *$ & $0.356^{\mathrm{ns}}$ & $0.123^{\mathrm{ns}}$ & $0.734 * *$ & $0.695^{*}$ \\
\hline BMŽ1 & & & & & & 1 & $0.997 * * *$ & $-0.933^{* *}$ & $0.980 * * *$ & $-0.367^{\mathrm{ns}}$ & $-0.080^{\mathrm{ns}}$ & $-0.792 * *$ & $-0.757 * *$ \\
\hline BSŽ1 & & & & & & & 1 & $-0.926^{* *}$ & $0.990 * * *$ & $-0.368^{\mathrm{ns}}$ & $-0.073^{\mathrm{ns}}$ & $-0.766^{* *}$ & $-0.729 * *$ \\
\hline QS & & & & & & & & 1 & $-0.888 * * *$ & $0.361^{\text {ns }}$ & $0.250^{\mathrm{ns}}$ & $0.910 * * *$ & $0.885 * * *$ \\
\hline QSŽ1 & & & & & & & & & 1 & $-0.390^{\mathrm{ns}}$ & $-0.062^{\mathrm{ns}}$ & $-0.680^{*}$ & $-0.638^{*}$ \\
\hline EK & & & & & & & & & & 1 & $0.674 *$ & $0.277^{\mathrm{ns}}$ & $0.285^{\text {ns }}$ \\
\hline UKS & & & & & & & & & & & 1 & $0.272^{\mathrm{ns}}$ & $0.291^{\mathrm{ns}}$ \\
\hline EKŽ1 & & & & & & & & & & & & 1 & $0.998 * * *$ \\
\hline UKSŽ1 & & & & & & & & & & & & & 1 \\
\hline
\end{tabular}

$*$,**,***Significant at $\mathrm{P}<0.05,0.01,0.001$;

1. V Height of plant 2. VE Height of the first fertile floor $(\mathrm{sm}) 3$. BETŽ Number of fertile floor

4. BM Number of pods 5. BS Number of seeds 6. BMŽ1 Number of pods on the first fertile floor

7. BSŽ1 Number of seeds on the first fertile floor 8. QS 1000 seeds weight per plant 9. QSŽ1 1000 seeds weight on the first fertile floor 10. EK Energy of seed germination 11. UKS Seed germination 12. EKŽ1 Energy of seed germination on the first fertile floor 13. UKSŽ1 Seed germination on the first fertile floor.

Correlations between energy and seed germination per plant, on the one hand, and plant height, height of first fertile floor, the number of fertile floors, number of pods and seeds per plant, number of pods and seeds on the first fertile floor, seed weight per plant and seed weight on the first fertile floor, on the other hand were not statistically significant. Energy of seed germination on the first fertile floor was positively correlated with plant height $(\mathrm{r}=0,935)$, height of first fertile floor $(r=0,986)$, the number of fertile floors $(r=0,779)$, number of pods $(r$ $=0,767)$ and seeds per plant $(\mathrm{r}=0,734)$ as well as seed weight per plant $(\mathrm{r}=0,910)$. It also showed a negative correlation with number of pods $(r=-0,792)$ and seeds on the first fertile floor $(r=-0,766)$ and seed weight on the first fertile floor $(r=-$ 0,680 ). Seed germination on the first fertile floor was positively correlated with 
plant height $(\mathrm{r}=0,913)$, height of first fertile floor $(\mathrm{r}=0,983)$, the number of fertile floors $(r=0,742)$, number of pods $(r=0,730)$ and seeds per plant $(r=0,695)$ as well as seed weight per plant $(\mathrm{r}=0,885)$ and negative correlation with number of pods $(\mathrm{r}$ $=-0,757)$ and seeds on the first fertile floor $(r=-0,729)$ and seed weight on the first fertile floor $(r=-0,638)$.

\section{Uticaj prve rodne etaže na kvalitativno -kvantitativna svojstva semena soje}

\section{S. Anđelović, S. Maksimovic, D. Savić, Z. Tomic, D. Delić}

\section{Rezime}

Cilj istraživanja bio je utvrđivanje uticaja visine PRVE rodne etaže na kvalitativno-kvantitativna svojstva semena soje. Kod kvalitativnih svojstava akcenat je stavljen na energiju klijanja i ukupnu klijavost semena istraživanih genotipova posebno po biljci i prvoj rodnoj etaži. Sumiranjem rezultata istraživanja, utvrđene su značajne razlike između genotipova, posmatrano po morfološkim karakteristikama (visina biljaka, visina prve rodne etaže, broj rodnih etaža, broj mahuna i semena, masa semena i dr) kao i kod kvalitativnih svojstava energije klijanja i ukupna klijavost semena. Sorta Gorštak sa genetički inkorporiranom visokom prvom rodnom etažom $(12,38 \mathrm{~cm})$ bila je dominantna $\mathrm{u}$ odnosu na druga dva genotipa. Sličan trend je utvrđen i kod drugih morfoloških analiza. Energija klijanja i ukupna klijavost semena svih rodnih etaža, posmatrano po genotipovima, nije pokazala značajne razlike. Međutim, od izuzetnog značaja su utvrđene vrednosti ovih parametara kada je reč o prvoj rodnoj etaži. Sorta Gorštak imala je vrlo značajnu veću vrednost energije klijanja (90,46\%) kao i ukupnu klijavost semena $(91,00 \%)$ u odnosu na druga dva genotipa.

\section{References}

ANĐELOVIĆ S., PLAZINIĆ V., MARIĆ M., JOVANOVIĆ B. (2000): Vegetation area, yield components and seed quality. Collection of scientific works, INI Agroekonomik, Belgrade, 6, 117-121.

AĆIMOVIĆ M. (1988): The agents of soybean diseases and their control. Scientific Book, Belgrade, 69-80.

BRIM C.A. (1973): Soybeans:-Improvement, Production and Uses, Quantitative Genetics and Breeding, Madison, Wisconsin, Chapter 5, 155-183, 
CHUNG J., BARKA STASWICK H.L. P.E., LEE D.J., GREGAN P.B., SHOEMAKER R.C., SPECHT J.E. (2003): The seed protein, oil and yield QTL on soybean linkage group I. Crop Sci., 43, 1053-1067.

PLAZINIĆ V. (1987): Contribution to the influence of genotypic and phenotypic variation in soybean seed. Archives of Agricultural Sciences, Belgrade, 48-68.

PLAZINIĆ V., ANDJELOVIĆ S., NENADIĆ N. (1999): Inheritance of first fertile floor in the new BG-lines. Collection of scientific works, INI Agroekonomik, Belgrade, 183-190.

SCOTT O.W., ALDRICH S.R. (1970): Modern Soybean Production. Champaign J., USA 11 ,

SINCLAIR J.B., SHURTLEFF M.C. (1975): Compendium of Soybean Diseases. The American Phytopatological Society, St. Paul, Minn., USA.

WHIGHAM D.K., MINOR H.C.(1978): Effect of Temperature on Growth and Development. Soybean Biology, Agronomy and Utilization. Academic Press inc London. 